Canadian Journal of Plant Science Revue canadienne de phytotechnie

\title{
Nitrogen and Seeding Rate versus Novel Inputs for Western Canada Canola Production
}

\begin{tabular}{|r|l|}
\hline Journal: & Canadian Journal of Plant Science \\
\hline Manuscript ID & CJPS-2016-0138.R1 \\
\hline Manuscript Type: & Article \\
\hline Date Submitted by the Author: & 31 -May-2016 \\
\hline Complete List of Authors: & $\begin{array}{l}\text { Harker, Neil; AAFC, } \\
\text { Hartman, Murray; Alberta Agriculture, Food \& Rural Development, }\end{array}$ \\
\hline Keywords: & Agronomy, Boron, Canola, Nitrogen, Seed \\
\hline
\end{tabular}




\title{
Nitrogen and Seeding Rate versus Novel Inputs for Western Canada Canola Production
}

\author{
K. Neil Harker ${ }^{1}$ and Murray D. Hartman ${ }^{2}$ \\ ${ }^{1}$ Agriculture and Agri-Food Canada, Lacombe Research and Development Centre, 6000 C \& E \\ Trail, Lacombe, Alberta, Canada T4L 1W1 (e-mail: neil.harker@agr.gc.ca); ${ }^{2}$ Alberta Agriculture \\ and Forestry, 5030 - 50 Street, Lacombe, Alberta, Canada T4L 1 W8.
}

A canola (Brassica napus L.) experiment to determine the effect of unconventional or novel inputs compared to standard and increased seed and nitrogen rates was conducted at fourteen different Alberta and Saskatchewan, Canada sites in 2013 and 2014. All treatments were compared to a "best management practice" (BMP) treatment with canola seeded at 100 seeds $\mathrm{m}^{-2}$ and fertilized according to soil test recommendations. Canola density across all sites averaged 56 plants $\mathrm{m}^{-2}$ and increased to 76 plants $\mathrm{m}^{-2}$ at 150 seeds $\mathrm{m}^{-2}$. Flowering and maturity time were both decreased when $25 \%$ less nitrogen was applied in the side-band at seeding. Compared to the BMP treatment, there were trends for lower yield $(P=0.0528)$ when sidebanded nitrogen was reduced by $25 \%$ at seeding time or for higher yield $(P=0.0530)$ when $25 \%$ more nitrogen was added as a foliar treatment at the bud stage. Canola yields were generally economically optimized in the BMP treatment at soil test recommended nitrogen rates. Increasing the seeding rate from 100 to 150 seeds $\mathrm{m}^{-2}$ did not increase canola yield; however, it did decrease \% green seed enough to potentially affect canola grade and economic returns. Increasing or decreasing nitrogen fertilizer compared to BMP often decreased or increased seed oil concentration, respectively, and had the opposite effect on seed protein concentration. 
Despite incurring additional costs, compared to the BMP treatment, none of the novel inputs impacted canola emergence, days to flowering, days to maturity, yield or quality.

Key words: Agronomy, Brassica napus L., boron, canola, nitrogen, seed 
High yielding canola is dependent on favourable environmental conditions, agronomic inputs and management. Adequate and uniform precipitation (Harker et al. 2015b) and the avoidance of high temperatures during flowering and pod development (Harker et al. 2012b, Kutcher et al. 2010; Nuttall et al. 1992; Polowick and Sawhney 1988; Young et al. 2004) allow canola to achieve high yield. Early seeding (Clayton et al. 2004; Dosdall et al. 1996; Kirkland and Johnson 2000) and early time of weed removal (Clayton et al. 2002; Harker et al. 1999, 2008; Martin et al. 2001); both favour high canola yields. Planting sufficient seed is also important to achieve adequate plant densities for optimal canola yields (Brandt et al. 2007; Hanson et al. 2008; Harker et al. 2003, 2012b). Balanced soil nutrients are key canola yield determinants (Grant and Bailey 1993; Karamanos et al. 2005); nitrogen is particularly important (Blackshaw et al. 2011; Cutforth et al. 2009; Harker et al. 2012b; Smith et al. 2010).

Crop input usage is influenced by crop and input prices, perceptions about input efficacy and grower attitudes towards innovation and risk. Standard inputs such as nitrogen and hybrid seed are indispensable to achieve canola yield targets (Brandt et al 2007; Harker et al. 2003, 2012). Inputs such as fungicide may improve canola yields in some situations but not others (Brandt et al 2007; Harker et al. 2012b). When canola prices are relatively high, growers become interested in higher rates of standard inputs that may further increase yields and profits. Furthermore, with more favourable crop prices producers may also become more interested in less conventional or novel inputs such as micronutrients, "stress relief" and "crop stimulation" products. For example, boron use has been gaining in popularity by canola growers in spite of research that indicates a low probability for yield response in western Canada (Karamanos et al., 2003; Malhi et al., 2003). 
A wide variety of products are promoted with claims to increase canola yields through a variety of mechanisms. Many include plant micronutrients that can be beneficial if sufficient quantities are not available in the soil. Some are advertised as growth promoters while others claim to mitigate plant stress during and after inclement weather. There are product claims to increase photosynthesis by releasing $\mathrm{CO}_{2}$ near crop leaves. Unfortunately independent data confirming the putative yield responses of these products are scarce. The purpose of this study was to compare some unconventional and novel products to varying levels of standard inputs such as nitrogen and seeding rate. Specifically, we were interested in comparing these treatments to a standard "best management practice" (BMP) for nitrogen and seed rate.

\section{MATERIALS AND METHODS}

Field experiments were conducted at 14 different Alberta (AB) and Saskatchewan (SK), Canada sites in 2013 and/or 2014 (Table 1). At each site a popular canola hybrid (glufosinate- or glyphosate-resistant treated seed) chosen by the site coordinator was seeded in mid-May (except for two sites in early June) on small-grain cereal stubble that had been treated with glyphosate (450 to $900 \mathrm{~g}$ ae $\mathrm{ha}^{-1}$ ) to control emerged weeds. Unless specified otherwise in the treatment structure, all plots were seeded at 100 viable seeds $\mathrm{m}^{-2}$ and fertilized with $\mathrm{N}, \mathrm{P}, \mathrm{K}$ and S according to soil test recommendations for a reasonable dryland or irrigated yield target for each site (Table 2 for nitrogen rates). Soil test $\mathrm{NO}_{3}-\mathrm{N}(0-60 \mathrm{~cm})$ at these sites ranged from low to high, and minor adjustments to the rate treatments were needed when recommendations were very low at the high residual $\mathrm{NO}_{3}-\mathrm{N}$ sites. Seeders included disc, hoe or knife openers on 
20- to 30-cm row spacings at a target seed depth of $1 \mathrm{~cm}$. Fertilizer $\left(\mathrm{N}, \mathrm{P}_{2} \mathrm{O}_{5}, \mathrm{~K}_{2} \mathrm{O}, \mathrm{S}\right)$ was sidebanded during planting $2 \mathrm{~cm}$ beside and 3-4 cm below the seed row or mid-row banded before or during seeding. At most sites a small amount of nitrogen $\left(3 \mathrm{~kg} \mathrm{~N} \mathrm{ha}{ }^{-1}\right)$ and phosphorous (15 $\mathrm{kg} \mathrm{P}_{2} \mathrm{O}_{5} \mathrm{ha}^{-1}$ ) ("starter fertilizer") was placed within the canola seed-row. Herbicides, fungicides and insecticides were applied as needed across all plots to prevent yield loss from weeds, insects and diseases.

At most sites, thirteen treatments were imposed in a randomized complete block design with four replications (a few sites in 2013 conducted by Applied Research Associations included only the first 6 treatments).

1. The BMP treatment was a canola seeding rate of 100 seeds $\mathrm{m}^{-2}$ fertilized according to soil test recommendations ( $100 \%$ fertilizer $\mathrm{N}$ rate).

2. $125 \%$ fertilizer nitrogen rate at seeding in side-band (see Table 2 )

3. Protinus seed primer treatment (http://wolftrax.com/products/protinus/) 4g per kg canola seed

4. C3 "stress reliever" applied at $2.47 \mathrm{~L} / \mathrm{ha}$ with first in-crop herbicide (http://omexcanada.com/c3)

5. $100 \%$ fertilizer at seeding with an additional $25 \% \mathrm{~N}$ as foliar applied $28-0-0$ at bud stage

6. Boron (Nexus $10 \%$ B) foliar applied at $2.47 \mathrm{~L} /$ ha at $5 \%$ flowering stage (http://www.nexusag.com/products/label NexusLiquidBoron.pdf)

7. Higher seeding rate of 150 seeds $\mathrm{m}^{-2}$ 
8. $75 \%$ fertilizer $\mathrm{N}$ rate at seeding in side-band (see Table 2 )

9. Precede seed primer (http://www.atpnutrition.ca/products/precede/precedecanola/) at $6 \mathrm{ml} / \mathrm{kg}$ canola seed

10. Penergetic-p biostimulator (http://www.penergetic.ca/penergetic-p.html) at 123.5 $\mathrm{g} /$ ha applied at the first true leaf and again at the rosette stage

11. Fortified foliar fertilizer supplement at $5 \mathrm{~L} /$ ha between 5 -leaf stage to bolting (https://www.alpinepfl.com/west/products/fertilizer-products/product/alpinefortified-foliar/)

12. Boron (Alpine MicroBolt B) $1.85 \mathrm{~L} / \mathrm{ha}$ at 4-6 leaf stage (https://www.alpinepfl.com/west/products/fertilizer-products/product/alpine$\underline{\text { fortified-foliar/) }}$

13. AGROSOLution $\mathrm{CO}_{2}$ uptake enhancer $2.5 \mathrm{~kg} / \mathrm{ha}$ at 2 to 4 leaf stage and $3 \mathrm{~kg} / \mathrm{ha}$ two weeks later (http://greenfield-fertilizer.com/wordpress/wpcontent/uploads/AGROSOLution-ENG sm.pdf)

Plot dimensions varied from $2 \times 6 \mathrm{~m}$ to $3 \times 15 \mathrm{~m}$. With the exception of treatment 8 , all treatments included an input in addition (+) to the BMP treatment; treatment 8 was BMP minus (-) $25 \%$ of side-banded nitrogen. The High Prairie site seeding rate was approximately 200 seeds $\mathrm{m}^{-2}$ in their limited six treatment trial. At Outlook in 2014, this irrigated site targeted 150 and 225 seeds $\mathrm{m}^{-2}$ for the standard and higher seeding rates respectively. In 2013, the Scott site did not include foliar N (treatment 5), and in 2014 the Swift Current site did not include Protinus (treatment 3). 
Data collection included crop emergence density (two, side-by-side, 1-m rows at two representative places in each plot 2 to 3 wk after crop emergence), days to flowering and days to maturity. Canola was harvested with plot combines and yield was corrected to $8.5 \%$ moisture content. Canola 1000 seed weights were determined in cleaned seed samples. Percent green seed was determined visually at each site using three samples of 100 rolled seeds from each plot. Canola seed oil and protein concentration ( $8.5 \%$ moisture basis) were determined using a near infrared reflectance spectrometer (Foss Model 6500, FOSS NIRSystems Inc., Silver Spring, MD, USA). Not all sites collected all data (see footnotes in Figs. 1-8). Furthermore, detectable differences in days to flowering and days to maturity were not detected at some sites (the data did not vary); these data were excluded from statistical analyses. Weather data was collected from stations nearest each field site (Table 3).

\section{Statistical Analysis}

Data from five [St. Isidore, AB (2013), Fort Vermilion, AB (2014), Medicine Hat, AB (2014), Prince Albert, SK (2014) and St. Paul, AB (2014)] of the nineteen site years were not included due to various issues such as seeding and treatment errors, adverse weather conditions (such as flooding) and excessive variation. Obvious data outliers were removed from the remaining sites after they were detected using PROC UNIVARIATE (SAS Institute 2011). Data were then analyzed using SAS PROC MIXED (Littel et al. 2006; SAS Institute 2011). Treatment effects were considered as fixed effects. Replicate and environment (years and sites) effects and environment interactions with fixed effects were considered random. Given our desire of 
making treatment inferences beyond study sites, it was appropriate to consider environment effects and their interactions with fixed effects as random (Yang 2010). In agronomic experiments with limited replication, Type II errors (acceptance of the null hypothesis when it is false) are more common than Type I errors (rejection of the null hypothesis when it is true) (Carmer and Walker 1988). Treating sites as random effects increased statistical power to facilitate the detection of differences that were not always apparent when analyzing individual site data.

The main objective of this study was to compare various treatments to a BMP. Preplanned single degree-of-freedom contrasts between each individual treatment versus the BMP treatment were declared significant at $P<0.05$. For significant dependent variables, when the environment by treatment interaction was significant and accounted for approximately $5 \%$ of the total environment plus environment by treatment variance, data from specific environments were discussed to help explain the environment by treatment interaction.

\section{RESULTS AND DISCUSSION}

\section{Canola Emergence Density}

Average canola density across all sites for the 100 seeds $\mathrm{m}^{-2}$ rate was 56 plants $\mathrm{m}^{-2}$ and site means varied from 22 to 81 plants $\mathrm{m}^{-2}$ (Table 4). Across site emergence varied from $51 \%$ for treatment 7 (higher seeding rate) to $58 \%$ in the BMP (Fig. 1). Other studies confirm just over $50 \%$ emergence of planted canola seed (Harker et al. 2012a, 2015a). Given that treatment 7 
was a $50 \%$ higher seeding rate, it is not surprising that the treatment effect for crop emergence was highly significant. No other treatments influenced canola emergence. The environment by treatment interaction explained $4 \%$ of the total environment variation (Table 3); much of that variation was due to the unexpected fact that five of nine sites did not detect an emergence difference between the 150 seeds $\mathrm{m}^{-2}$ seeding rate (trt. 7) and treatment 1 at the 100 seeds $\mathrm{m}^{-2}$ seeding rate (Fig. 1., Site compliance, NS).

\section{Days to Flowering}

Flowering time was not generally influenced by the treatments we imposed (Table 4, Fig. 2). However, at two of five sites with usable data, and for the across all sites mean, less nitrogen in the sideband (trt. 8) hastened flowering time. Canola ends vegetative growth and initiates flowering more quickly when nitrogen is limiting (Brandt et al. 2007). The agronomic significance of earlier flowering is limited given the small effect and the fact that limiting nitrogen will usually also limit seed yield.

\section{Days to Maturity}

Time to canola maturity was not usually impacted by the treatments in this study (Table 4, Fig. 3). However, like days to flowering, the across site mean indicated slightly faster canola maturity when less nitrogen was applied during seeding (trt. 8); two of six sites also detected a similar effect. Brandt et al. (2007) reported the same effect. None of the other treatments 
influenced the time of maturity. Although the across site mean was not significant, it is notable that additional nitrogen at seeding (trt. 2) delayed maturity at two of seven sites (Fig. 3., Site compliance, D+).

\section{Canola Seed Yield}

Seed yield site means varied from 1,023 to 5,762 $\mathrm{kg} \mathrm{ha}^{-1}$ (Table 4). None of the treatments led to canola yields that differed from BMP (trt. 1) (Fig. 4). Our results are consistent with previous western Canada research showing micronutrient seed primers did not increase yield (Holzapfel et al. 2011). There were trends for lower yield across all sites $(P=0.0528)$ when nitrogen was reduced by $25 \%$ at seeding time (trt. 8$)$ as well as higher yield across all sites $(P=0.0530)$ when $25 \%$ more nitrogen was added as a foliar treatment (trt. 5). Yields were fairly similar between $125 \% \mathrm{~N}$ applied at seeding or as a foliar in-crop. The contrast for all $125 \% \mathrm{~N}$ treatments combined was a similar strong trend $(P=0.0539)$ for higher yield compared to the BMP and not surprisingly, was higher yielding than $75 \% \mathrm{~N}(\mathrm{P}=0.0001)$.

Adding $25 \%$ more nitrogen as a foliar treatment (trt. 5) increased canola yields compared to BMP at two of thirteen sites (Medicine Hat and Beaverlodge), while adding $25 \%$ nitrogen in the side-band at seeding (trt. 2) increased canola yields at only one of 14 sites, Medicine Hat (Fig. 4., Site compliance, D+). Medicine Hat in 2013 experienced several moderate hailstorms through the summer, and the extra $\mathrm{N}$ likely benefitted regrowth and late season yield compensation. In fact, $25 \%$ more $\mathrm{N}$ (just $16 \mathrm{~kg} \mathrm{~N} \mathrm{ha}^{-1}$ ) at this site produced $269 \mathrm{~kg} \mathrm{ha}^{-1}$ more canola. At average 2013-14 canola prices and urea fertilizer cost $\left(\$ 500 \mathrm{~T}^{-1}\right.$ and $\$ 625 \mathrm{~T}^{-1}$ 
respectively) the marginal returns from this extra fertilizer was more than $\$ 100 \mathrm{ha}^{-1}$. Although one of the boron marketing claims is improved canola recovery and yield after hail, the two boron treatments at Medicine Hat in 2013 did not increase yield.

The Beaverlodge 2013 yields were unusual: the BMP was statistically lower yielding than six of the treatments and numerically lower than all other treatments. This BMP yield with $100 \% \mathrm{~N}$ is likely spurious since it was statistically lower than both $75 \% \mathrm{~N}$ and $125 \% \mathrm{~N}$.

This trial was not designed as a detailed $\mathrm{N}$ response experiment which would require more rate levels including a zero nitrogen fertilizer check. The goal for including the $125 \% \mathrm{~N}$ treatments was to assess the value of additional $\mathrm{N}$ fertilizer at either seeding time or top dressing, compared to the BMP or spending on unconventional inputs. The $75 \%$ rate was included to help determine if the site was $\mathrm{N}$ responsive. However, simple production economics can still be applied. The two $125 \% \mathrm{~N}$ treatments averaged $94 \mathrm{~kg} \mathrm{ha}^{-1}$ more canola yield than the BMP across all sites (Fig. 4), while the $75 \% \mathrm{~N}$ treatment was $116 \mathrm{~kg} \mathrm{ha}^{-1}$ lower yielding than the BMP. This indicates that the fertilizer rates studied were in the diminishing returns area of the $\mathrm{N}$ response curve. Average $\mathrm{N}$ increments in the fertilizer treatments across all sites used for yield analysis were approximately $25 \mathrm{~kg} \mathrm{~N} \mathrm{ha}^{-1}$. Assuming the average 2013-14 prices for canola and $\mathrm{N}$ urea fertilizer stated above, increasing $\mathrm{N}$ from $75 \%$ to $100 \%$ and $100 \%$ to $125 \%$ increased net returns by $\$ 24$ and $\$ 13 \mathrm{ha}^{-1}$ respectively. The marginal rate of returns on these fertilizer increments were 1.7 and 1.4 respectively. Often, a ratio of 1.5 is used as a cut-off for purchasing additional input considering risk and other factors. Using that cut-off level, the increase in fertilizer $\mathrm{N}$ from 75 to $100 \%$ was economically feasible; in contrast there 
was insufficient profit incentive to increase from 100 to $125 \% \mathrm{~N}$. Thus the $100 \% \mathrm{~N}$ rate used in these trials based on soil test recommendations were reasonable targets for economic $\mathrm{N}$ fertilization. All other treatments tested did not statistically improve yield over the BMP, and thus net returns from their use would obviously be negative.

Other recent western Canadian studies confirming nitrogen's crucial influence on hybrid canola yield involved 50\% increases or decreases in nitrogen rates (Brandt et al 2007; Harker et al. 2003, 2012). Blackshaw et al. (2011) reported a canola yield response to $50 \%$ additional nitrogen for 10 of 20 site-years. When sufficient nitrogen is present at seeding $(100 \%$ of soil test recommendation), additional nitrogen may be more effective when applied later in the season rather than simply adding more at seeding time. Given slower and later nitrogen release, polymer-coated nitrogen increased canola yields in some situations (Blackshaw et al. 2011).

Increased seeding rates may increase canola yield in some situations (Brandt et al. 2007; Harker et al. 2012b). Such was not the case in the current study $(P=0.3643)$; only one site (had greater yields at the higher seeding rate (Fig. 4., Site compliance, D+). However, in both studies cited above, the seeding rates that yielded less than higher rates were lower than the BMP seeding rate in this study (100 seeds $\left.\mathrm{m}^{-2}\right)$. Therefore, the occurrence of seeding rate responses depends on the level of the lowest seeding rate. Here, we determined that it was not beneficial to canola yield to increase seeding rates beyond 100 seeds $\mathrm{m}^{-2}$. An average canola plant density of 57 plants $\mathrm{m}^{-2}$ (Table 3 ) is sufficient to optimize yield (CCC 2015a). 
Approximately $25 \%$ of western Canadian canola growers apply boron to enhance canola production (CCC personal communication, Curtis Rempel). No across-site boron response was detected in this study (Fig. 4). Of the 12 site-years analyzed where boron was applied at the 4to 6-leaf stage, one site had a $14 \%$ yield increase over the BMP (2793 to $3178 \mathrm{~kg} \mathrm{ha}^{-1}, \mathrm{P}=$ 0.0187, Beaverlodge 2013). However, this site had unusually low BMP yields as discussed above. Of the 14 site-years analyzed where boron was applied at the flowering stage, yield increased $13 \%$ at one site (2793 to $3152 \mathrm{~kg} \mathrm{ha}^{-1}, \mathrm{P}=0.0276$, Beaverlodge 2013) and decreased $14 \%$ at another site (3309 to $2898 \mathrm{~kg} \mathrm{ha}^{-1}, \mathrm{P}=0.0299$, Lethbridge 2013). There were only a few sites that had very low soil test boron $\left(0.15-0.50 \mathrm{mg}\right.$ boron $\mathrm{kg}^{-1}$ soil, hot water extractable, Ahmed et al., 2012). Soil test summaries have reported that boron-deficient soils are infrequent in western Canada (Flaten et al., 2000). In a large study of canola response to boron in western Canada, Karamanos et al. (2003) concluded that the hot-water extractable boron soil test is not an effective diagnostic tool for determining boron status. The results from this experiment agrees with previous research (Karamanos et al., 2003; Malhi et al., 2003) that significant canola yield responses to boron fertilizer applications are rare in western Canada, and thus general applications of boron are not warranted. There were very high yields achieved in some sites with no boron effect, and this refutes the idea that high yielding hybrid canola is becoming limited by boron in western Canada.

\section{Seed Weight}


Canola seed weights were not influenced by any of the treatments in our experiment (Table 4, Fig. 5). Seed weights averaged $3.45 \mathrm{~g}$ and ranged from 2.96 to $3.96 \mathrm{~g}$ at individual sites. Seed weights can be influenced by canola population differences (Harker et al. 2003, 2015a), but the effect is not consistent (Angadi et al. 2003; McGregor 1987). At Beaverlodge in 2013, the higher seeding rate (trt. 7) increased 1000 seed weight from $3.49 \mathrm{~g}$ (BMP) to $3.84 \mathrm{~g}$ (data not shown) (Fig. 5, Site compliance, D+).

\section{Green Seed}

The lowest- and highest-site green seed percentage ranged from 0 to 5.9\% (Table 4). Although the treatment effect $P$-value was not significant $(P=0.5306)$, a single degree-of-freedom contrast detected less green seed at the higher seeding rate (trt. 7) versus BMP $(P=0.0306)$

(Fig. 6). Treating sites as random effects for green seed data provided sufficient statistical power to detect a treatment difference (Carmer and Walker 1988) that was not detectable at eight of nine sites. Although across-site green seed means were below the $2 \%$ threshold for canola grade and price reduction (CCC 2015b), it is important to document that maintaining adequate seeding rates can help mitigate against quality and profit losses due to green seed levels in canola. Others have reported that higher seeding rates can reduce green seed levels (Brandt et al. 2007; Harker et al. 2013; Morrison et al. 1990).

The environment by treatment interaction explained $5 \%$ of the total environment variation (Table 4). At one of three sites where average green seed levels were above $2 \%$ (Manning 2013), the higher seeding rate treatment reduced green seed levels from $6.8 \%$ in the 
BMP treatment to $2.2 \%(P=0.0006)$ (data not shown). At Lacombe in 2014 where average green seed levels were $0.5 \%$, the higher nitrogen treatment in the side-band at seeding (trt. 2) increased green seed levels from $0.3 \%$ in the BMP treatment to $0.9 \%(P=0.0003)$ (data not shown). When seeding is delayed, or low canola emergence occurs, or when fall frost risks are more likely, then the management of green seed levels and subsequent economic returns can be influenced by seeding rates and applied nitrogen.

\section{Oil Concentration}

Reducing nitrogen by $25 \%$ at seeding time (trt. 8 ) increased canola seed oil concentration compared to BMP $(\mathrm{P}<0.0001$, Table 4, Fig. 7). Similar results have been reported previously in western Canada (Malhi and Gill, 2004; Brandt et al. 2007; Karamanos et al. 2007; Harker et al. 2012b) and internationally (Brennan et al., 2000; Rathke et al., 2005). The effect was not significant at nine of ten sites, but the experimental power gained by treating environments as random effects enabled us to detect a significant reduced nitrogen effect. None of the other treatments influenced across site treatment means.

\section{Protein Concentration}

As expected, canola seed protein concentration tended to increase with higher applied nitrogen (Brennan et al. 2000; Harker et al. 2013; Karamanos et al. 2007; Malhi and Gill, 2004; May et al. 2010). Reducing nitrogen by $25 \%$ at seeding time (trt. 8 ) decreased protein concentration 
compared to BMP (P = 0.0006, Table 4, Fig. 8). In contrast, additional foliar-applied nitrogen (trt. 5) increased protein concentration compared to BMP $(P=0.0097)$. Once again, only one to three individual environments were able to detect these significant effects. The trend for increased protein due to extra nitrogen in the side-band at seeding (trt. 2) was not significant (P $=0.2720)$.

\section{CONCLUSIONS}

Planting 100 canola seeds $\mathrm{m}^{-2}$ led to an average plant density across all sites of 56 plants $\mathrm{m}^{-2}$. Flowering and maturity time were both slightly decreased when $25 \%$ less nitrogen was applied in the side-band at seeding. There were strong trends for greater canola yield with $25 \%$ more nitrogen as a liquid foliar treatment or for less canola yield with $25 \%$ less nitrogen applied in the side-band at seeding. Canola yields were economically optimized in the BMP treatment at soil test recommended nitrogen rates. Increasing the seeding rate from 100 to 150 seeds $\mathrm{m}^{-2}$ did not increase canola yield since an adequate number of plants were established to reach full yield potential. Increasing the seeding rate to 150 seeds $\mathrm{m}^{-2}$ decreased $\%$ green seed by almost $1 \%$; on the Canadian Prairies this decrease in green seed levels has important quality, grading and price implications. Increasing or decreasing nitrogen often decreased or increased seed oil concentration, respectively, and had the opposite effect on seed protein concentration. Boron fertilization did not increase canola yield across sites, and thus, should not be recommended as a general practice. Despite incurring additional costs, none of the less conventional inputs had any impact on canola emergence, days to flowering, days to maturity, yield or quality. Growers 
should be careful to ensure that canola seed and nitrogen inputs are optimized before they consider paying for novel or less conventional inputs.

\section{ACKNOWLEDGEMENTS}

The assistance of site leaders and technical staff is appreciated: G. Semach (Beaverlodge, AB), K. Gill and J. P. Pettyjohn (Big Lakes and St. Isidore, AB), A. Eyolfson (Forestburg, AB), J. Marfo (Fort Vermilion, AB), L. Michielsen, P. Reid, E. Sroka and J. Zuidhof (Lacombe, AB), K. Coles and M. Gretzinger (Lethbridge and Medicine Hat, AB), T. Fromme (Manning, AB), G. Hnatowich (Outlook, SK), G. Lewko and L. White (Prince Albert, SK), T. Coehlo and L. Grenkow (Scott, SK), A. Krone (St. Paul, AB) and B. Nybo and D. Sluth (Swift Current, SK). We are grateful for the help from Canola Council of Canada agronomists. We also acknowledge the funding support of Agriculture \& Agri-Food Canada, the Alberta Canola Producers Commission, the Saskatchewan Canola Development Commission, the Manitoba Canola Growers Association and the Canola Council of Canada. 
Ahmad, W., Zia, M.H., Malhi, S.S., Niaz, A., and Saifullah. 2012. Boron Deficiency in Soils and Crops: A Review. Chapter 5, Crop Plant, Dr. Aakash Goyal (Ed.), ISBN: 978-953-51-0527-5, InTech. Available from: http://www.intechopen.com/books/crop-plant/boron-deficiencyin-soils-and-crops-a-review

Angadi, S.V., Cutforth, H.W., McConkey, B.G., and Gan, Y. 2003. Yield adjustment by canola grown at different plant populations under semiarid conditions. Crop Sci. 43: 1358-1366.

Blackshaw, R.E., Hao, X., Brandt, R.N., Clayton, G.W., Harker, K.N., O’Donovan, J.T., Johnson, E.N., and Vera, C.L. 2011. Canola response to ESN and urea in a four-year no-till cropping system. Agron. J. 103: 92-99.

Brandt, S.A., Malhi, S.S., Ulrich, D., Lafond, G.P., Kutcher, H.R., and Johnston, A.M. 2007. Seeding rate, fertilizer level and disease management effects on hybrid versus open pollinated canola (Brassica napus L.). Can. J. Plant Sci. 87: 255-266.

Brennan, R.F., Mason, M.G., and Walton, G.H. 2000. Effect of nitrogen fertilizer on the concentrations of oil and protein in canola (Brassica napus) seed. J. Plant Nutr. 23: 339348.

[CCC] Canola Council of Canada. 2015a. Plant Population - Crop Establishment - Canola Encyclopedia. Web page: http://www.canolacouncil.org/canola-encyclopedia/cropestablishment/plant-population/ [accessed: 18 December 2015].

[CCC] Canola Council of Canada. 2015b. Chapter 12 - Storage, conditioning - Canola Grower's Manual. Web page: http://www.canolacouncil.org/crop-production/canola-grower's- 


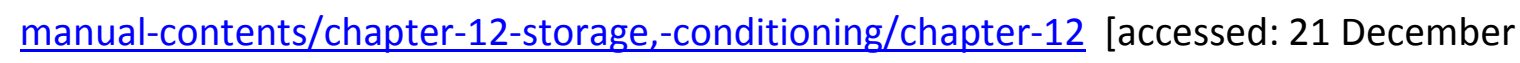
2015].

Carmer, S.G., and Walker, W.M. 1988. Significance from a statistician's viewpoint. J. Prod. Agric. 1: $27-33$.

Clayton, G.W., K.N. Harker, J.T. O’Donovan, M.N. Baig, and M.J. Kidnie. 2002. Glyphosate timing and tillage system effects on glyphosate-tolerant canola (Brassica napus). Weed Technol. 16: $124-130$.

Clayton, G.W., Harker, K.N., O'Donovan, J.T., Blackshaw, R.E., Dosdall, L.M., Stevenson, F.C., and Ferguson, T. 2004. Fall and spring seeding date effects on herbicide-tolerant canola (Brassica napus L.) cultivars. Can. J. Plant Sci. 84: 419-430.

Cutforth, H., McConkey, B., Brandt, S., Gan, Y., Lafond, G., Angadi, S., and Judiesch, D. 2009. Fertilizer $\mathrm{N}$ response and canola yield in the semiarid Canadian prairies. Can. J. Plant Sci. 89: 501-503.

Dosdall, L.M., Herbut, M.J., Cowle, N.T., and Micklich, T.M. 1996. The effect of seeding date and plant density on infestations of root maggots, Delia spp. (Diptera: Anthomyiidae), in canola. Can. J. Plant Sci. 76: 169-177.

Flaten, P., Green, B., and Routledge, P. 2000. Trends in micro-nutrient soil test levels in Saskatchewan. Soils and Crops Workshop (http://www.usask.ca/soilsncrops/conferenceproceedings/previous years/Files/2000/2000docs/327.pdf) [accessed: 1 March 2016]. 
Grant, C.A., and Bailey, L.D. 1993. Fertility management in canola production. Can. J. Plant Sci 73: $651-670$.

Hanson, B.K., Johnson, B.L., Henson, R.A., and Riveland, N.R. 2008. Seeding rate, seeding depth, and cultivar influence on spring canola performance in the Northern Great Plains. Agron. J. 100: 1339-1346.

Harker, K.N., Clayton, G.W., Blackshaw, R.E., O’Donovan, J.T., and Stevenson, F.C. 2003. Seeding rate, herbicide timing and competitive hybrids contribute to integrated weed management in canola (Brassica napus). Can. J. Plant Sci. 83: 433-440.

Harker, K.N., Clayton, G.W., and Johnston, A.M. 1999. Time of weed removal for canola. Proc. $10^{\text {th }}$ International Rapeseed Congress. Sep. 26-29, Canberra, Australia. Website: http://www.regional.org.au/au/gcirc/2/352.htm\#TopOfPage. [accessed: 7 December 2015].

Harker, K.N., O’Donovan, J.T., Blackshaw, R.E., Hall, L.M., Willenborg, C.J., Kutcher, H.R., Gan, Y., Lafond, G.P., May, W.E., Grant, C.A., Barthet, V., McDonald, T., Wispinski, D., and Hartman, M. 2013. Seeding depth and seeding speed effects on no-till canola emergence, maturity, yield and seed quality. Can. J. Plant Sci. 92: 795-802.

Harker, K.N., O’Donovan, J.T., Blackshaw, R.E., Johnson, E.N., Lafond, G.P., and May, W.E. 2012a. Seeding depth and seeding speed effects on no-till canola emergence, maturity, yield and seed quality. Can. J. Plant Sci. 92: 795-802. 
Harker, K.N., O’Donovan, J.T., Clayton, G.W., and Mayko, J. 2008. Field-scale time of weed removal in canola (Brassica napus L.). Weed Technol. 22: 747-749.

Harker, K.N., O’Donovan, J.T., Smith, E.G., Johnson, E.N., Peng, G., Willenborg, C.J., Gulden, R.H., Mohr, R., Gill, K.S., and Grenkow, L.A. 2015a. Seed size and seeding rate effects on canola emergence, development, yield and seed weight. Can. J. Plant Sci. 95: 1-8.

Harker, K.N., O’Donovan, J.T., Turkington, T.K., Blackshaw, R.E., Lupwayi, N.Z., Smith, E.G., Johnson, E.N., Gan, Y., Kutcher, H.R., Dosdall, L.M., and Peng, G. 2015b. Canola rotation frequency impacts canola yield and associated pest species. Can. J. Plant Sci. 95: 9-20.

Harker, K.N., O’Donovan, J.T., Turkington, T.K., Blackshaw, R.E., Lupwayi, N.Z., Smith, E.G., KleinGebbinck, H., Dosdall, L.M., Hall, L.M., Willenborg, C.J., Kutcher, H.R., Malhi, S.S., Vera, C.L., Gan, Y., Lafond, G.P., May, W.E., Grant, C.A., and McLaren, D.L. 2012b. High-yield notill canola production on the Canadian Prairies. Can. J. Plant Sci. 92: 221-233.

Holzapfel, C., Kirk, A., Nybo, B., and Severson, A. 2011. 2011 yield-busters - micronutrient seed dressing effects on various crops. Pages 5-9 in Indian Head Agricultural Research Foundation 2011 Annual Report. Web page: http://iharf.ca/wpcontent/uploads/2014/11/2011-IHARF-annual-report.pdf [accessed: 3 May 2016].

Karamanos, R.E., Goh, T.B., and Flaten, D.N. 2007. Nitrogen and sulphur fertilizer management for growing canola on sulphur sufficient soils. Can. J. Plant Sci. 87: 201-210.

Karamanos, R.E., Goh, T.B., and Stonehouse, T.A. 2003. Canola response to boron in Canadian prairie soils. Can. J. Plant Sci. 83: 249-259. 
Kirkland, K.J., and Johnson, E.N. 2000. Alternative seeding dates (fall and April) affect Brassica napus canola yield and quality. Can. J. Plant Sci. 80: 713-719.

Kutcher, H.R., Warland, J.S., and Brandt, S.A. 2010. Temperature and precipitation effects on canola yields in Saskatchewan, Canada. Agric. Forest Meteorol. 150: 161-165.

Littel, R.C., Milliken, G.A., Stroup, W.W., and Wolfinger R.D. 2006. SAS System for Mixed Models (2nd ed.) SAS Institute, Cary NC. 813 pp.

Malhi, S.S., and Gill, K.S. 2004. Placement, rate and source of N, seedrow opener and seeding depth effects on canola production. Can. J. Plant Sci. 84: 719-729.

Malhi, S.S., Raza, M., Schoenau, J.J., Mermut, A.R., Kutcher, R., Johnston, A.M., and Gill, K.S. 2003. Feasibility of boron fertilization for yield, seed quality and B uptake of canola in northeastern Saskatchewan. Can. J. Soil Sci. 83: 99-108.

Martin, S.G., Friesen, L.F., and Van Acker, R.C. 2001. Critical period of weed control in spring canola. Weed Sci. 49: 326-333.

May, W.E., Brandt, S.A., Gan, Y., Kutcher, H.R., Holzapfel, C.B., and Lafond, G.P. 2010. Adaption of oilseed crops across Saskatchewan. Can J. Plant Sci. 90: 667-677.

McGregor, D.I. 1987. Effect of plant density on development and yield of rapeseed and its significance to recovery from hail injury. Can. J. Plant Sci. 67: 43-51.

Morrison, M.J., McVetty, P.B.E., and Scarth, R. 1990. Effect of row spacing and seeding rates on summer rape in Southern Manitoba. Can. J. Plant Sci. 70: 127-137. 
Nuttall, W.F., Moulin, A.P., and Townley-Smith, L.J. 1992. Yield response of canola to nitrogen, phosphorus, precipitation, and temperature. Agron. J. 84: 765-768.

Polowick, P.L., and Sawhney, V.K. 1988. High temperature induced male and female sterility in canola (Brassica napus L.). Ann. Bot. 62: 83-86.

Rathke, G.W., Christen, O., and Diepenbrock, W. 2005. Effects of nitrogen source and rate on productivity and quality of winter oilseed rape (Brassica napus L.) grown in different crop rotations. Field Crops Res. 94: 103-113.

SAS Institute. 2011. SAS/STAT ${ }^{\circledR} 9.3$ User's Guide. SAS Institute Inc., Cary, NC.

Smith, E.G., Upadhyay, B.M., Favret, M.L., and Karamanos, R.E. 2010. Fertilizer response for hybrid and open-pollinated canola and economic optimal nutrient levels. Can. J. Plant Sci. 90: $305-310$.

Yang, R.-C. 2010. Towards understanding and use of mixed-model analysis of agricultural experiments. Can. J. Plant Sci. 90: 605-627.

Young, L.W., Wilen, R.W., and Bonham-Smith, P.C. 2004. High temperature stress of Brassica napus during flowering reduces micro- and megagametophyte fertility, induces fruit abortion, and disrupts seed production. J. Exp. Bot. 55: 485-495. 


\begin{tabular}{|c|c|c|c|c|c|c|}
\hline Site & Year & Soil type & Soil texture & Soil pH & Boron & Seeding date \\
\hline & & & & & (ppm) & \\
\hline \multirow[t]{2}{*}{ Beaverlodge, $A B$} & 2013 & Dark Gray Chernozem & Clay loam & 5.6 &.$^{a}$ & May 16 \\
\hline & 2014 & & & 6.2 & 0.9 & May 18 \\
\hline High Prairie, $A B$ & 2013 & Gray Luvisol & Clay loam & 6.1 & 0.4 & May 20 \\
\hline Forestburg, $A B$ & 2013 & Black Chernozem & Clay loam & 6.3 & 0.9 & May 16 \\
\hline Fort Vermilion, $A B$ & 2014 & Gray Luvisol & Sandy loam & 6.5 & 0.7 & May 23 \\
\hline \multirow[t]{2}{*}{ Lacombe, AB } & 2013 & Black Chernozem & Loam & 6.4 & 1.5 & May 15 \\
\hline & 2014 & & & 6.9 & 2.1 & May 13 \\
\hline \multirow[t]{2}{*}{ Lethbridge, $A B$} & 2013 & Dark Brown Chernozem & Clay loam & 8.0 & . & May 11 \\
\hline & 2014 & & & 8.1 & . & May 12 \\
\hline Manning, $A B$ & 2013 & Gray Luvisol & Clay loam & 5.6 & 0.9 & May 24 \\
\hline \multirow[t]{2}{*}{ Medicine Hat, AB } & 2013 & Brown Chernozem & Sandy loam & 8.0 & . & May 16 \\
\hline & 2014 & & & 7.9 & 0.5 & May 13 \\
\hline Outlook, SK & 2014 & Brown Chernozem & Clay loam & 8.0 & . & May 21 \\
\hline Prince Albert, SK & 2014 & Black Chernozem & Loam & 5.9 & . & June 2 \\
\hline \multirow[t]{2}{*}{ Scott, SK } & 2013 & Dark Brown Chernozem & Loam & 6.0 & . & May 15 \\
\hline & 2014 & & & 6.4 & 0.7 & May 21 \\
\hline St. Isidore, $A B$ & 2013 & Gray Luvisol & Heavy clay & 5.6 & 0.3 & May 17 \\
\hline St. Paul, AB & 2014 & Dark Gray Chernozem & Loam & 6.0 & 1.1 & June 3 \\
\hline Swift Current, SK & 2014 & Brown Chernozem & Loam & 6.8 & 0.6 & May 14 \\
\hline
\end{tabular}

\footnotetext{
${ }^{\mathrm{a}}$ Soil boron level not available.
} 


\begin{tabular}{|c|c|c|c|c|c|}
\hline \multirow[b]{2}{*}{ Site } & \multirow[b]{2}{*}{ Year } & \multirow{2}{*}{$\begin{array}{l}\text { Soil test } \\
\mathrm{NO}_{3}-\mathrm{N}\end{array}$} & \multicolumn{3}{|c|}{ Applied nitrogen } \\
\hline & & & $75 \%$ & $100 \%$ & $125 \%$ \\
\hline & & 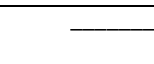 & - & & - \\
\hline \multirow[t]{2}{*}{ Beaverlodge, $A B$} & 2013 & 60 & 65 & 87 & 108 \\
\hline & 2014 & 22 & 88 & 111 & 133 \\
\hline High Prairie, $A B$ & 2013 & 51 &.$^{a}$ & 100 & 126 \\
\hline Forestburg, $A B$ & 2013 & 56 & . & 79 & 98 \\
\hline Fort Vermilion, $A B$ & 2014 & 97 & 29 & 39 & 47 \\
\hline \multirow[t]{2}{*}{ Lacombe, AB } & 2013 & 55 & 104 & 138 & 171 \\
\hline & 2014 & 39 & 108 & 140 & 173 \\
\hline \multirow[t]{2}{*}{ Lethbridge, $A B$} & 2013 & 145 & 53 & 70 & 88 \\
\hline & 2014 & 60 & 84 & 112 & 140 \\
\hline Manning, $A B$ & 2013 & 89 & 28 & 37 & $68^{b}$ \\
\hline \multirow[t]{2}{*}{ Medicine Hat, AB } & 2013 & 49 & 49 & 65 & 81 \\
\hline & 2014 & 4 & 63 & 84 & 105 \\
\hline Outlook, SK & 2014 & 210 & 83 & 110 & 138 \\
\hline Prince Albert, SK & 2014 & 53 & 67 & 90 & 112 \\
\hline \multirow[t]{2}{*}{ Scott, SK } & 2013 & 24 & & 109 & 136 \\
\hline & 2014 & 13 & 75 & 100 & 125 \\
\hline St. Isidore, $A B$ & 2013 & 28 & & 100 & 126 \\
\hline St. Paul, AB & 2014 & 176 & 57 & 87 & $118^{\mathrm{c}}$ \\
\hline Swift Current, SK & 2014 & 24 & 84 & 112 & 140 \\
\hline
\end{tabular}

\footnotetext{
${ }^{\mathrm{a}}$ The $75 \%$ nitrogen treatment was not included at these 2013 sites.

${ }^{\mathrm{b}}$ More than $125 \%$ nitrogen applied (184\%).

${ }^{c}$ More than $125 \%$ nitrogen applied (136\%).
} 


\begin{tabular}{|c|c|c|c|c|c|c|c|c|c|c|c|c|}
\hline & & \multicolumn{10}{|c|}{ Precipitation } & \multirow{3}{*}{$\begin{array}{c}\text { Temperature } \\
\text { May-Aug } \\
\text { \# days }>30 \mathrm{C}\end{array}$} \\
\hline & & \multicolumn{2}{|c|}{ May } & \multicolumn{2}{|c|}{ June } & \multicolumn{2}{|c|}{ July } & \multicolumn{2}{|c|}{ August } & \multicolumn{2}{|c|}{ May-Aug } & \\
\hline & & Actual & $\%$ LTA & Actual & $\%$ LTA & Actual & $\%$ LTA & Actual & $\%$ LTA & Actual & $\%$ LTA & \\
\hline & & & & & & $-1 \mathrm{~m}$ & m) - & & & & & \\
\hline \multirow[t]{2}{*}{ Beaverlodge, $A B$} & 2013 & 34 & 82 & 82 & 128 & 70 & 97 & 69 & 118 & 254 & 108 & 1 \\
\hline & 2014 & 3 & 7 & 59 & 92 & 79 & 109 & 3 & 5 & 143 & 61 & 5 \\
\hline High Prairie, $A B$ & 2013 & 26 & 62 & 118 & 143 & 115 & 137 & 33 & 57 & 293 & 109 & 1 \\
\hline Forestburg, $A B$ & 2013 & 24 & 57 & 81 & 108 & 63 & 83 & 60 & 104 & 228 & 91 & 2 \\
\hline Fort Vermilion, $A B$ & 2014 & 16 & 43 & 58 & 104 & 37 & 34 & 13 & 12 & 123 & 40 & 18 \\
\hline \multirow[t]{2}{*}{ Lacombe, $A B$} & 2013 & 66 & 129 & 71 & 85 & 133 & 164 & 71 & 110 & 342 & 122 & 2 \\
\hline & 2014 & 47 & 92 & 76 & 91 & 68 & 84 & 28 & 43 & 220 & 78 & 1 \\
\hline \multirow[t]{2}{*}{ Lethbridge, $A B^{2}$} & 2013 & 55 & 106 & 190 & 243 & 202 & 471 & 101 & 245 & 547 & 255 & 10 \\
\hline & 2014 & 46 & 86 & 205 & 249 & 167 & 395 & 116 & 289 & 534 & 245 & 11 \\
\hline Manning, $A B$ & 2013 & 31 & 82 & 79 & 151 & 58 & 68 & 22 & 32 & 191 & 78 & 3 \\
\hline \multirow[t]{2}{*}{ Medicine Hat, $A B$} & 2013 & 29 & 67 & 41 & 60 & 113 & 287 & 37 & 113 & 220 & 120 & 25 \\
\hline & 2014 & 37 & 86 & 88 & 129 & 27 & 68 & 110 & 323 & 262 & 141 & 21 \\
\hline Outlook, SK ${ }^{\mathrm{a}}$ & 2014 & 81 & 224 & 98 & 155 & 28 & 55 & 27 & 73 & 234 & 125 & 3 \\
\hline Prince Albert, SK & 2014 & 58 & 134 & 156 & 229 & 88 & 119 & 67 & 110 & 369 & 150 & 1 \\
\hline \multirow[t]{2}{*}{ Scott, SK } & 2013 & 39 & 108 & 114 & 189 & 26 & 44 & 63 & 141 & 242 & 121 & 3 \\
\hline & 2014 & 23 & 64 & 60 & 101 & 128 & 217 & 30 & 67 & 242 & 121 & 0 \\
\hline St. Isidore, $A B$ & 2013 & 33 & 80 & 168 & 231 & 89 & 131 & 20 & 40 & 311 & 133 & 1 \\
\hline St. Paul, AB & 2014 & 54 & 125 & 94 & 130 & 71 & 88 & 15 & 26 & 234 & 92 & 0 \\
\hline Swift Current, SK & 2014 & 34 & 68 & 117 & 146 & 34 & 62 & 106 & 233 & 290 & 126 & 4 \\
\hline
\end{tabular}

Irrigated sites (irrigation amounts at Outlook are not included in the Table). 


\begin{tabular}{|c|c|c|c|c|c|c|c|c|}
\hline \multirow[b]{2}{*}{ Variable $^{x}$} & \multirow{2}{*}{$\begin{array}{l}\text { Overall } \\
\text { mean }\end{array}$} & \multirow{2}{*}{$\begin{array}{c}\text { Treatment } \\
\text { effect } \\
\text { P-value }\end{array}$} & \multirow{2}{*}{$\begin{array}{c}\text { Lowest } \\
\text { environment } \\
\text { mean }\end{array}$} & \multirow{2}{*}{$\begin{array}{c}\text { Highest } \\
\text { environment } \\
\text { mean }\end{array}$} & \multirow{2}{*}{$\begin{array}{c}\text { Ex T } \\
\text { P-value }\end{array}$} & \multicolumn{2}{|c|}{ Variance estimates } & \multirow[b]{2}{*}{$\%^{b}$} \\
\hline & & & & & & $E$ & $\mathrm{E} \times \mathrm{T}$ & \\
\hline Crop emergence $\left(\# \mathrm{~m}^{-2}\right)^{\mathrm{c}}$ & 56 & $<0.0001$ & 22 & 81 & 0.0229 & 243 & 10 & 4.0 \\
\hline Days to flowering (d) & 51 & 0.3468 & 47 & 56 & $<0.0001$ & 12.33 & 0.14 & 1.1 \\
\hline Days to maturity (d) & 105 & 0.0686 & 92 & 121 & $<0.0001$ & 94.05 & 0.23 & 0.2 \\
\hline Yield $\left(\mathrm{kg} \mathrm{ha}^{-1}\right)$ & 3,504 & 0.0758 & 1,023 & 5,762 & 0.2822 & 1345889 & 1805 & 0.1 \\
\hline 1000 seed weight (g) & 3.45 & 0.8277 & 2.96 & 3.96 & 0.5830 & 0.2036 & 0 & 0.0 \\
\hline Green seed (\%) & 1.4 & 0.4498 & 0.0 & 5.9 & 0.0001 & 3.43 & 0.18 & 5.0 \\
\hline Seed oil content (\%) & 44.6 & 0.0002 & 42.5 & 47.4 & 0.1457 & 2.64 & 0.01 & 0.4 \\
\hline Seed protein content (\%) & 20.4 & 0.0001 & 16.5 & 22.6 & 0.0630 & 4.03 & 0.02 & 0.5 \\
\hline
\end{tabular}

${ }^{\mathrm{a}}$ Bolded $\mathrm{P}$-values for treatment effects are statistically significant $(\mathrm{P}<0.05)$.

${ }^{b}$ Environment by treatment interaction variance as a percent of the total environment plus the environment by treatment interaction variance.

${ }^{\mathrm{c}}$ Excludes treatment \#7 (higher seeding rate). 
Fig. 1. The effect of agronomic inputs on canola emergence density (means of 9 to 11 sites). BMP (treatment 1 ) = "Best Management Practice". The diagonal-filled bar indicates a value significantly greater than the BMP value (single degreeof-freedom contrast, $\mathrm{P}<0.05)$. Site compliance indicates \# of individual site contrasts to treatment 1 (BMP) in agreement with across site contrasts to treatment 1 shown in the Figure: " $A$ " = agreement, "NS" = not significant when across site contrast is significant, " $D+$ " = significant difference (same pattern) when across site contrast is not significant, "D-" = significant difference (opposite pattern). Emergence data from High Prairie and Outlook were excluded.

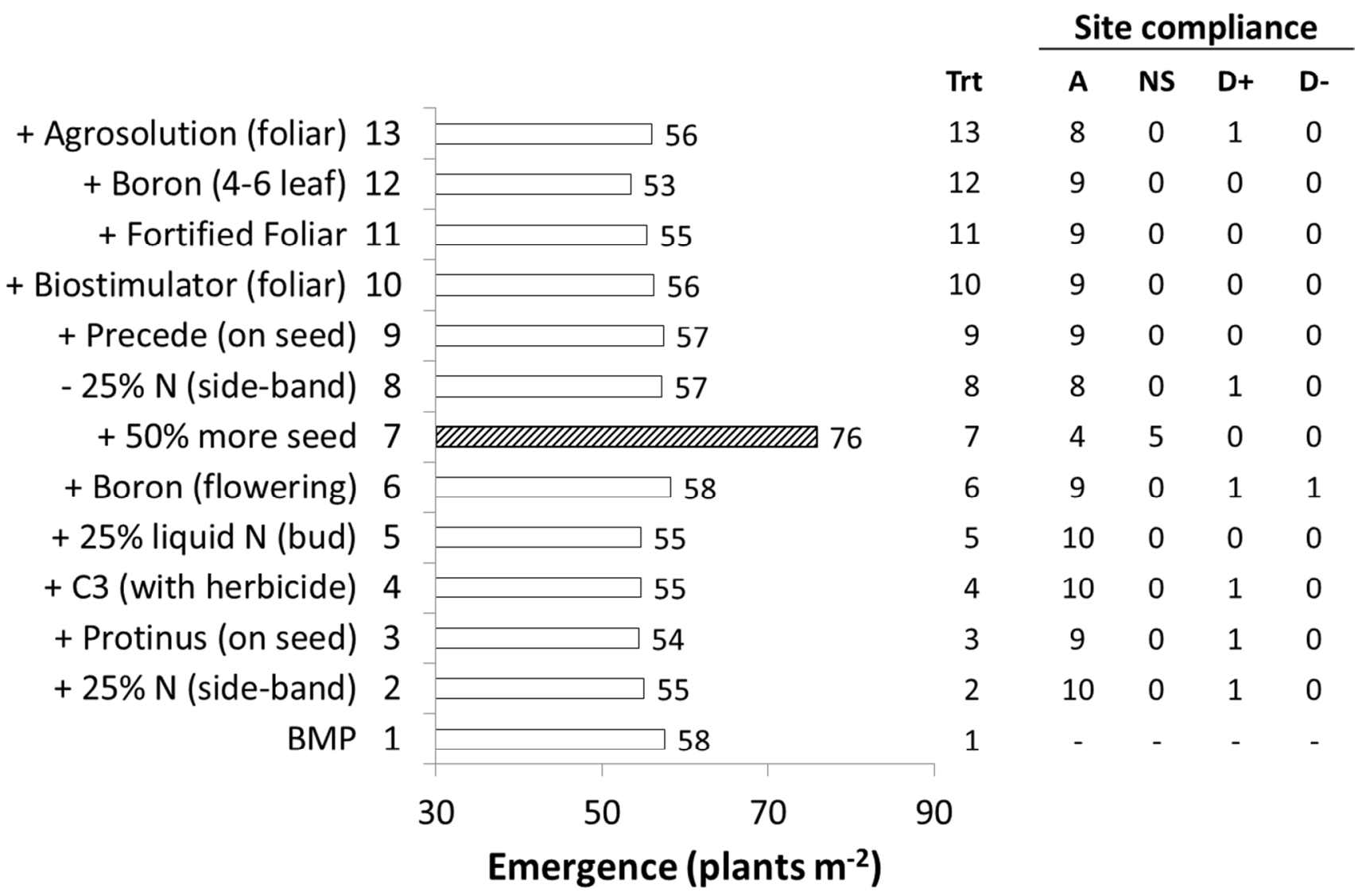


Fig. 2. The effect of agronomic inputs on the number of days after seeding to canola flowering (means of 5 to 6 sites). BMP (treatment 1) = "Best Management Practice". The black bar indicates a value significantly less than the BMP value (single degree-of-freedom contrast, $P<0.05$ ). Site compliance indicates \# of individual site contrasts to treatment 1 (BMP) in agreement with across site contrasts to treatment 1 shown in the Figure: " $A$ " = agreement, "NS" = not significant when across site contrast is significant, " $D+$ " = significant difference (same pattern) when across site contrast is not significant, "D-" = significant difference (opposite pattern.

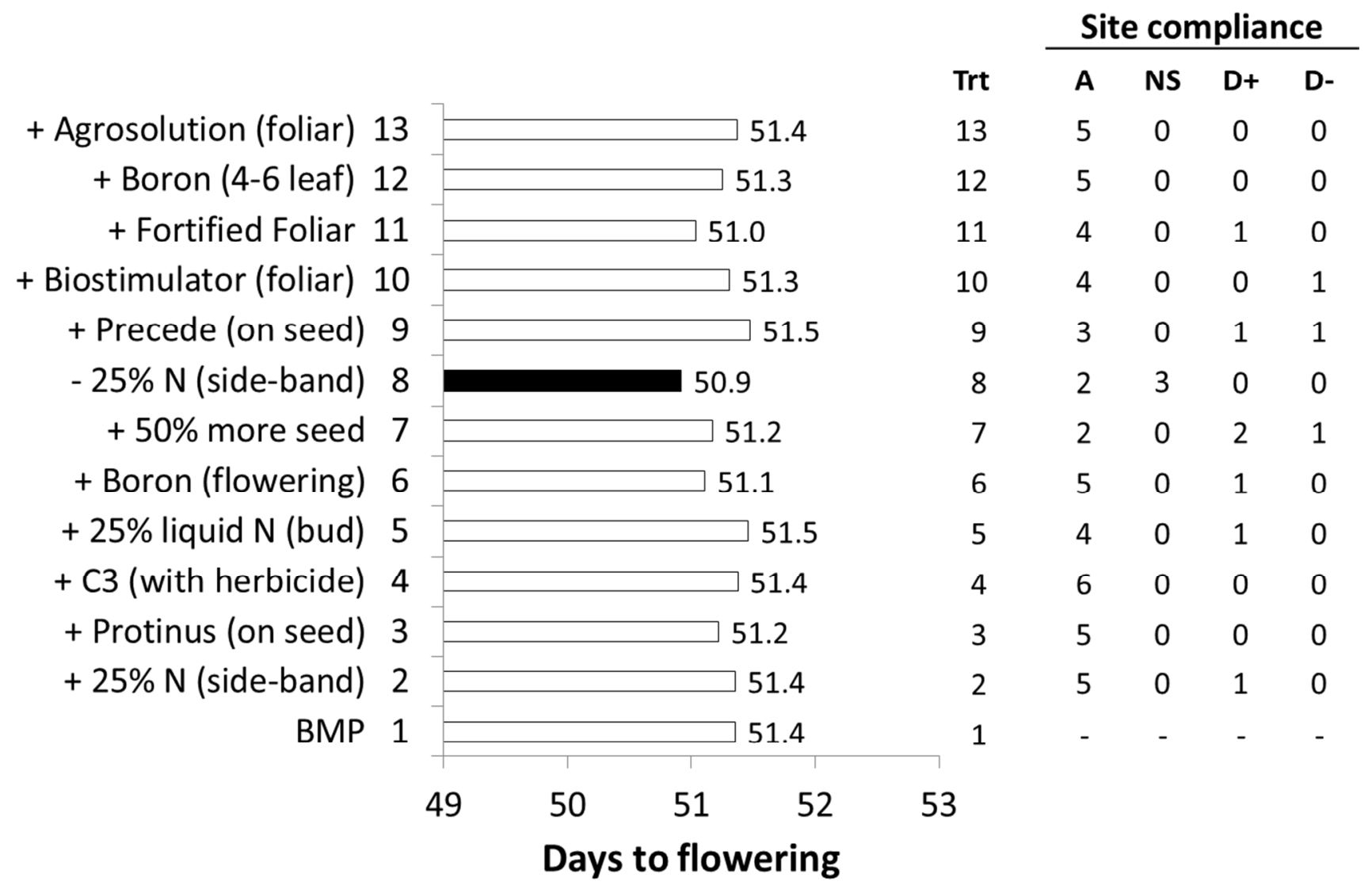


Fig. 3. The effect of agronomic inputs on the number of days after seeding to canola maturity (means of 6 to 7 sites). BMP (treatment 1) = "Best Management Practice". The black bar indicates a value significantly less than the BMP value (single degree-of-freedom contrast, $P<0.05$ ). Site compliance indicates \# of individual site contrasts to treatment 1 (BMP) in agreement with across site contrasts to treatment 1 shown in the Figure: " $A$ " = agreement, "NS" = not significant when across site contrast is significant, " $\mathrm{D}+$ " = significant difference (same pattern) when across site contrast is not significant, "D-" = significant difference (opposite pattern).

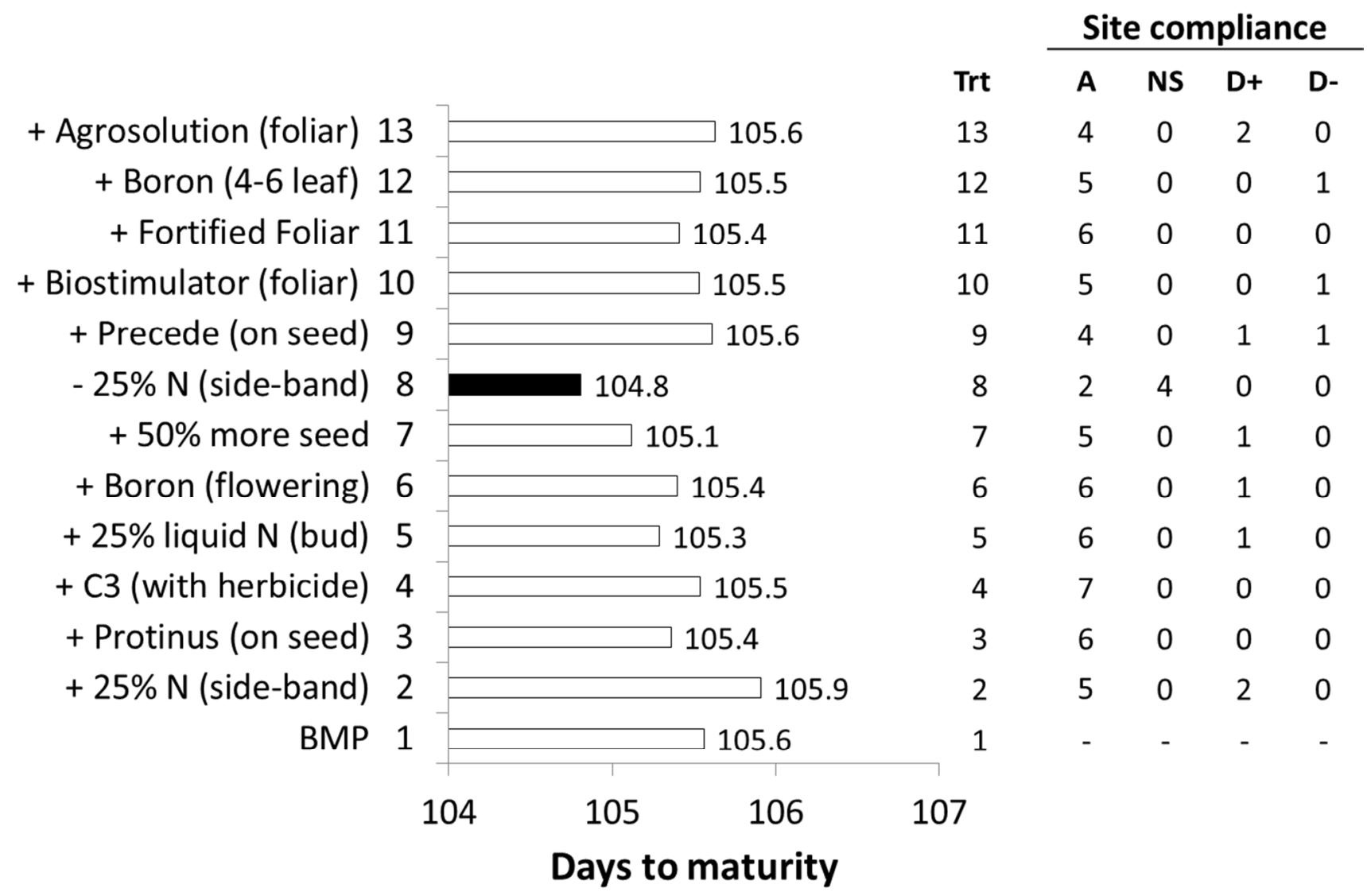


Fig. 4. The effect of agronomic inputs on canola seed yield (means of 11 to 14 sites). BMP (treatment 1 ) = "Best Management Practice". None of the values significantly differed from the BMP value (single degree-of-freedom contrast, $P<0.05$ ). Site compliance indicates \# of individual site contrasts to treatment 1 (BMP) in agreement with across site contrasts to treatment 1 shown in the Figure: " $\mathrm{A}$ " = agreement, "NS" = not significant when across site contrast is significant, " $D+$ " = significant difference (same pattern) when across site contrast is not significant, "D-" = significant difference (opposite pattern).

\begin{tabular}{|c|c|c|c|c|c|c|c|}
\hline & & & \multirow[b]{2}{*}{ Trt } & \multicolumn{4}{|c|}{ Site compliance } \\
\hline & & & & A & NS & D+ & D- \\
\hline + Agrosolution (foliar) 13 & & $\square 501$ & 13 & 10 & 0 & 1 & 0 \\
\hline + Boron (4-6 leaf) 12 & & $\checkmark 3472$ & 12 & 10 & 0 & 0 & 1 \\
\hline + Fortified Foliar 11 & & $\square 559$ & 11 & 11 & 0 & 0 & 0 \\
\hline + Biostimulator (foliar) 10 & & 3490 & 10 & 11 & 0 & 0 & 0 \\
\hline + Precede (on seed) & 9 & 3483 & 9 & 11 & 0 & 0 & 0 \\
\hline$-25 \% \mathrm{~N}$ (side-band) & 8 & $\square 3370$ & 8 & 10 & 0 & 0 & 1 \\
\hline$+50 \%$ more seed & 7 & 3540 & 7 & 10 & 0 & 1 & 0 \\
\hline+ Boron (flowering) $\epsilon$ & 6 & 3506 & 6 & 12 & 0 & 1 & 1 \\
\hline$+25 \%$ liquid $N$ (bud) 5 & 5 & $\checkmark 3596$ & 5 & 11 & 0 & 2 & 0 \\
\hline + C3 (with herbicide) & 4 & $\square 507$ & 4 & 13 & 0 & 1 & 0 \\
\hline+ Protinus (on seed) 3 & 3 & 3480 & 3 & 13 & 0 & 0 & 0 \\
\hline$+25 \% \mathrm{~N}$ (side-band) 2 & 2 & $\square 3564$ & 2 & 13 & 0 & 1 & 0 \\
\hline BMP 1 & 1 & 3486 & 1 & - & - & - & - \\
\hline & 3200 & $3400 \quad 3600$ & 3800 & & & & \\
\hline & & ieed yield (kg ha-1) & & & & & \\
\hline
\end{tabular}


Fig. 5. The effect of agronomic inputs on canola 1000 seed weight (means of 8 to 10 sites). BMP (treatment 1 ) = "Best Management Practice". None of the values significantly differed from the BMP value (single degree-of-freedom contrast, $P<0.05)$. Site compliance indicates \# of individual site contrasts to treatment 1 (BMP) in agreement with across site contrasts to treatment 1 shown in the Figure: " $A$ " = agreement, "NS" = not significant when across site contrast is significant, " $D+$ " = significant difference (same pattern) when across site contrast is not significant, "D-" = significant difference (opposite pattern).

$$
\begin{array}{rr}
\text { + Agrosolution (foliar) } & 13 \\
\text { + Boron (4-6 leaf) } & 12 \\
\text { + Fortified Foliar } & 11 \\
\text { + Biostimulator (foliar) } & 10 \\
\text { + Precede (on seed) } & 9 \\
\text { - 25\% N (side-band) } & 8 \\
\text { + 50\% more seed } & 7 \\
\text { + Boron (flowering) } & 6 \\
\text { + 25\% liquid N (bud) } & 5 \\
\text { + C3 (with herbicide) } & 4 \\
\text { + Protinus (on seed) } & 3 \\
\text { + 25\% N (side-band) } & 2 \\
\text { BMP } & 1
\end{array}
$$

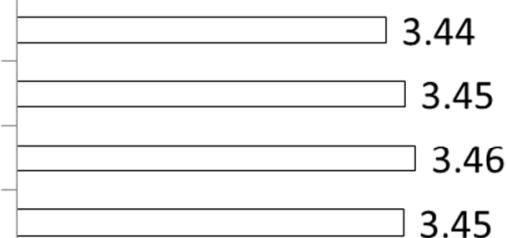

3.45

3.47

3.41

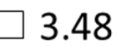

3.47

3.41

3.43

3.44

3.44

3.45
Site compliance

$\begin{array}{ccccc}\text { Trt } & \text { A } & \text { NS } & \text { D+ } & \text { D- } \\ 13 & 8 & 0 & 0 & 0 \\ 12 & 7 & 0 & 1 & 0 \\ 11 & 8 & 0 & 0 & 0 \\ 10 & 8 & 0 & 0 & 0 \\ 9 & 8 & 0 & 0 & 0 \\ 8 & 8 & 0 & 0 & 0 \\ 7 & 7 & 0 & 1 & 0 \\ 6 & 9 & 0 & 0 & 1 \\ 5 & 8 & 0 & 1 & 0 \\ 4 & 9 & 0 & 0 & 1 \\ 3 & 8 & 0 & 1 & 0 \\ 2 & 10 & 0 & 0 & 0 \\ 1 & - & - & - & -\end{array}$

\section{$\begin{array}{lllll}3.20 & 3.30 & 3.40 & 3.50 & 3.60\end{array}$ 1000 seed weight (grams)}


Fig. 6. The effect of agronomic inputs on $\%$ green canola seed (means of 9 to 11 sites). BMP (treatment 1 ) = "Best Management Practice". The black bar indicates a value significantly less than the BMP value (single degree-of-freedom contrast, $P<0.05)$. Site compliance indicates \# of individual site contrasts to treatment 1 (BMP) in agreement with across site contrasts to treatment 1 shown in the Figure: " $A$ " = agreement, "NS" = not significant when across site contrast is significant, " $D+$ " = significant difference (same pattern) when across site contrast is not significant, "D-" = significant difference (opposite pattern).

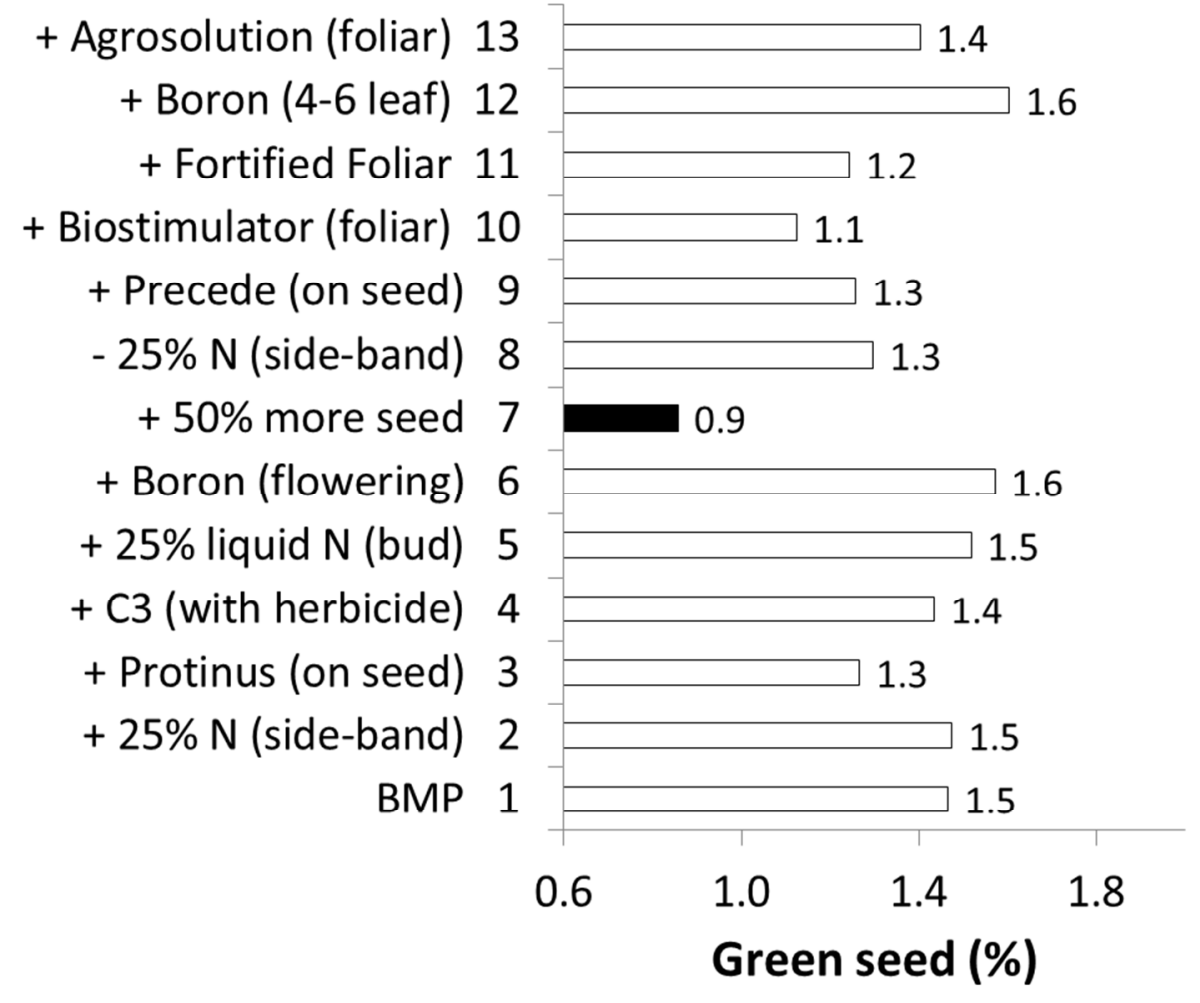

Site compliance

Trt A NS D+ D-

$\begin{array}{lllll}13 & 9 & 0 & 0 & 0\end{array}$

$\begin{array}{lllll}12 & 9 & 0 & 0 & 0\end{array}$

$\begin{array}{lllll}11 & 9 & 0 & 0 & 0\end{array}$

$\begin{array}{lllll}10 & 8 & 0 & 1 & 0\end{array}$

$\begin{array}{lllll}9 & 7 & 0 & 1 & 1\end{array}$

$8 \quad 9 \quad 0 \quad 000$

$\begin{array}{lllll}7 & 1 & 8 & 0 & 0\end{array}$

$\begin{array}{lllll}6 & 11 & 0 & 0 & 0\end{array}$

$\begin{array}{lllll}5 & 10 & 0 & 0 & 0\end{array}$

$\begin{array}{lllll}4 & 11 & 0 & 0 & 0\end{array}$

$\begin{array}{lllll}3 & 10 & 0 & 0 & 0\end{array}$

$\begin{array}{lllll}2 & 10 & 0 & 1 & 0\end{array}$
1

$\begin{array}{llll}0.6 & 1.0 & 1.4 & 1.8 \\ & \text { Green seed (\%) }\end{array}$


Fig. 7. The effect of agronomic inputs on canola oil content (means of 10 to 12 sites). BMP (treatment 1 ) = "Best Management Practice". The diagonal-filled bar indicates a value significantly greater than the BMP value (single degreeof-freedom contrast, $\mathrm{P}<0.05)$. Site compliance indicates \# of individual site contrasts to treatment 1 (BMP) in agreement with across site contrasts to treatment 1 shown in the Figure: " $A$ " = agreement, "NS" = not significant when across site contrast is significant, " $D+$ " = significant difference (same pattern) when across site contrast is not significant, "D-" = significant difference (opposite pattern).

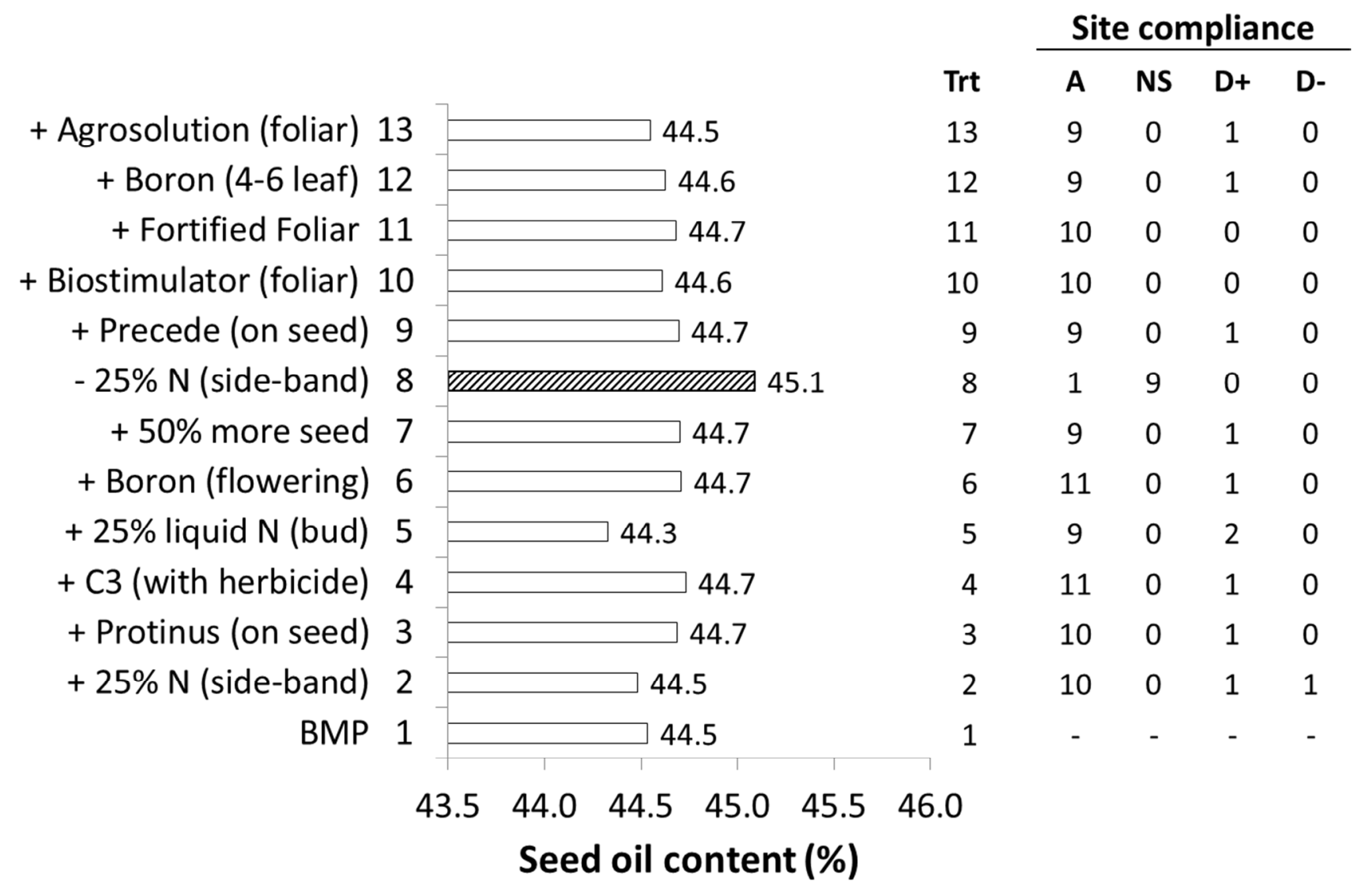


Fig. 8. The effect of agronomic inputs on canola protein content (means of 10 to 12 sites). BMP (treatment 1 ) = "Best Management Practice". The black bar indicates a value significantly less than the BMP value and the diagonal-filled bar indicates a value significantly greater than the BMP value (single degree-of-freedom contrasts, $\mathrm{P}<0.05$ ). Site compliance indicates \# of individual site contrasts to treatment 1 (BMP) in agreement with across site contrasts to treatment 1 shown in the Figure: " $A$ " = agreement, "NS" = not significant when across site contrast is significant, " $D+$ " = significant difference (same pattern) when across site contrast is not significant, "D-" = significant difference (opposite pattern).

\begin{tabular}{|c|c|c|c|c|c|c|}
\hline & & & & con & plia & \\
\hline & & Trt & A & NS & D+ & D- \\
\hline + Agrosolution (foliar) 13 & 20.5 & 13 & 10 & 0 & 0 & 0 \\
\hline + Boron (4-6 leaf) 12 & 20.4 & 12 & 10 & 0 & 0 & 0 \\
\hline + Fortified Foliar 11 & 20.3 & 11 & 10 & 0 & 0 & 0 \\
\hline + Biostimulator (foliar) 10 & 20.4 & 10 & 9 & 0 & 1 & 0 \\
\hline + Precede (on seed) 9 & 20.3 & 9 & 10 & 0 & 0 & 0 \\
\hline - $25 \% \mathrm{~N}$ (side-band) 8 & 20.0 & 8 & 1 & 9 & 0 & 0 \\
\hline$+50 \%$ more seed 7 & 20.3 & 7 & 9 & 0 & 1 & 0 \\
\hline+ Boron (flowering) 6 & 20.3 & 6 & 11 & 0 & 1 & 0 \\
\hline$+25 \%$ liquid $N$ (bud) 5 & 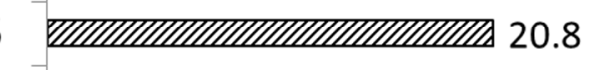 & 5 & 3 & 8 & 0 & 0 \\
\hline + C3 (with herbicide) 4 & $\square 20.3$ & 4 & 10 & 0 & 1 & 1 \\
\hline+ Protinus (on seed) 3 & 20.3 & 3 & 10 & 0 & 1 & 0 \\
\hline$+25 \% \mathrm{~N}$ (side-band) 2 & 20.6 & 2 & 10 & 0 & 2 & 0 \\
\hline BMP 1 & 20.5 & 1 & - & - & - & - \\
\hline & $\begin{array}{lllll}19.0 & 19.5 & 20.0 & 20.5 & 21.0\end{array}$ & 21.5 & & & & \\
\hline & Seed protein content ( $\%$ & & & & & \\
\hline
\end{tabular}

